\title{
DAMPAK IMPLEMENTASI PROGRAM PEKARANGAN PANGAN LESTARI (P2L) DI KECAMATAN GONDANGREJO KABUPATEN KARANGANYAR
}

\author{
Elisa Medi Saputri, Agung Wibowo, Eksa Rusdiyana \\ Fakultas Pertanian Universitas Sebelas Maret Jl. Ir Sutami 36A Surakarta Provinsi Jawa Tengah Indonesia
}

Koresponden Email: elisams1108@student.uns.ac.id

\begin{abstract}
Abstrak.
Pemanfaatan pekarangan sebagai tempat budidaya sayur mulai dikembangkan. Pengembangan pekarangan merupakan wujud dari implemenatasi program Pekarangan Pangan Lestari (P2L) dalam rangka pemenuhan kebutuhan gizi keluarga. Dampak-dampak yang diperoleh setelah melaksanakan program P2L menjadi indikator keberhasilan program tersebut. Program P2L yang tidak menuai hasil optimal dapat diindikasikan bahwa dalam pelaksanaannya tidak berjalan sesuai dengan konsep dan arahan yang diberikan. Perlunya evaluasi dari sisi pembuat dan pelaksana program untuk keberlanjutan program. Berdasarkan uraian permasalahan tersebut, penelitian ini bertujuan untuk menganalisis dampak implementasi program P2L di Kecamatan Gondangrejo Kabupaten Karanganyar. Metode penelitian menggunakan kualitatif deskriptif. Metode penentuan informan dalam penelitian adalah purposive dan snowball sampling. Hasil penelitian menunjukkan bahwa program P2L di Kecamatan Gondangrejo membawa dampak ekonomi melalui penghematan pengeluaran belanja sayur. Dampak sosial dapat dirasakan dengan adanya perubahan perilaku dan terbentuknya dinamika kelompok, secara psikologis terlihat adanya sikap wanita tani yang mau belajar budidaya sayur. Dampak program P2L apabila ditinjau dari aspek budaya belum terlihat. Program P2L tidak membawa dampak buruk bagi lingkungan.
\end{abstract}

Kata Kunci: Dampak, KWT, Program Pekarangan Pangan Lestari (P2L)

\begin{abstract}
.
Utilization of the yard as a place for vegetable cultivation began to be developed. The development of the yard is a manifestation of the implementation of The Sustainable Food Garden program (P2L) in order to meet the nutritional needs of the family. The P2L program brings various impacts that are felt by members of the Women Farmers Group (KWT) and their families. This study aims to analyze the impact of the implementation of the P2L program in Gondangrejo District, Karanganyar Regency. The method of determining the informants in this research is purposive sampling or intentionally. The results showed that the P2L program in Gondangrejo District had an economic impact through saving on vegetable spending. The social impact can be felt by changes in behavior and the formation of group dynamics, psychologically it can be seen that there is an attitude of female farmers who want to learn vegetable cultivation. The impact of the P2L program when viewed from a cultural aspect has not been seen. The P2L program does not have a negative impact on the environment.
\end{abstract}

\section{KeywordS : Impact, KWT, The Sustainable Food Garden (P2L) Program}

\section{PENDAHULUAN}

Pangan merupakan kebutuhan pokok yang sangat penting bagi kelangsungan hidup manusia. Produksi pangan yang tidak stabil dan keterbatasan dalam memenuhi kebutuhan pangan menjadi pendorong untuk diadakannya upaya-upaya penanggulangan. Salah satu upaya dalam pemenuhan ketahanan dan kemandirian pangan ditingkat rumah tangga dapat dilakukan melalui penganekaragaman pangan. Upaya penganekaragaman pangan sebagaimana disebutkan dalam Pasal 26 pada Peraturan Pemerintah Nomor 17 Tahun 2015 tentang
Ketahanan Pangan dan Gizi, salah satunya dapat melalui optimalisasi pemanfaatan lahan.

Program Pekarangan Pangan Lestari (P2L) dilaksanakan dalam rangka mendukung program pemerintah untuk penanganan daerah prioritas intervensi stunting dan/atau penanganan prioritas daerah rentan rawan pangan atau pemantapan daerah tahan pangan. Kegiatan ini dilakukan melalui pemanfaatan lahan pekarangan, lahan tidur dan lahan kosong yang tidak produktif, sebagai penghasil pangan dalam memenuhi pangan dan gizi rumah tangga, serta berorientasi pasar untuk meningkatkan pendapatan rumah tangga [1]. 
Program P2L di Indonesia merupakan program lanjutan dari program sebelumnya, yaitu Kawasan Rumah Pangan Lestari (KRP2L). Tahun 2020 menjadi awal pelaksanaan program P2L. Kecamatan Gondangrejo merupakan salah satu kecamatan yang ada di Kabupaten Karanganyar. Di kecamatan ini telah dilaksanakan program P2L yang melibatkan wanita tani setempat. Wanita tani yang termasuk kategori aktif dalam pelaksanaan program ditunjukkan dengan keikutsertaan kegiatan optimalisasi pemanfaatan lahan pekarangan yaitu pendampingan dan pelatihan, pengembangan demplot, pengembangan kebun bibit, praktik penyediaan menu, pengolahan hasil dan telah mengembangkan pekarannya masing-masing [2]. Keberhasilan program P2L sangat ditentukan oleh wanita tani sebagai ujung tombak atau eksekutor pelaksana program.

Program P2L harus membawa dampak bagi masyarakat terutama pelaksana program P2L. Kegiatan monitoring dan evaluasi yang dilakukan yaitu peninjauan kebun dan memantau hasil program, belum ada analisis khusus mengenai dampak program P2L itu sendiri. Tujuan penelitian ini adalah untuk menganalisis dampak implementasi program P2L di Kecamatan Gondangrejo Kabupaten Karanganyar. Penelitian ini diharapkan dapat digunakan sebagai referensi maupun pertimbangan untuk menyusun program dan kebijakan yang berkaitan dengan program P2L.

\section{MATERIAL DAN METODE}

Lokasi penelitian di Kecamatan Gondangrejo Kabupaten Karanganyar ditentukan secara sengaja (purposive), yaitu berdasarkan pertimbangan tertentu disesuaikan dengan tujuan penelitian [3]. Metode penentuan informan yang digunakan pada penelitian ini adalah sengaja (purposive sampling) dan snowball sampling dengan pertimbangan bahwa informan dapat memberikan informasi yang jelas mengenai pelaksanaan program $\mathrm{P} 2 \mathrm{~L}$ di Kecamatan Gondangrejo.

Informan ialah orang yang diwawancara dan diminta informasinya, atau orang yang diperkirakan menguasai dan memahami data, informasi atau fakta dari suatu obyek penelitian [4]. Informan dalam penelitian ini meliputi staf pada Dinas Pertanian PP Kabupaten Karanganyar, Penyuluh Pertanian di Ke Wilayah Kecamatan Gondangrejo, pengurus Kelompok
Wanita Tani (KWT), perangkat desa, dan perwakilan anggota KWT. Informan awal dipilih adalah orang yang bisa "membukakan pintu", pada penelitian ini yaitu PPL [5].

Dasar penelitian menggunakan pendekatan deskriptif dengan menekankan catatan deskripsi kalimat yang rinci, lengkap, mendalam yang menggambarkan situasi yang sebenarnya guna mendukung penyajian data. Tataran lanjut dari penelitian deskriptif adalah penelitian terapan jenis evaluasi, kebijakan, dan pengembangan atau tindakan [6]. Teknik pengumpulan data yang digunakan dalam penelitian ini adalah wawancara (interview) yang dilakukan kepada pihak-pihak yang berkaitan dengan KWT pelaksana program P2L. Wawancara adalah proses memperoleh keterangan untuk tujuan penelitian dengan cara tanya jawab antara si penanya atau pewawancara dengan si penjawab atau responden dengan menggunakan alat yang dinamakan interview guide (panduan wawancara) [7]. Dampak yang dianalisis pada penelitian ini yaitu pada aspek ekonomi, sosial, budaya, psikologis, dan dampak terhadap lingkungan.

\section{HASIL DAN PEMBAHASAN}

Program Pekarangan Pangan Lestari (P2L) diinisiasi oleh Badan Ketahanan Pangan (BKP) Kementerian Pertanian pada tahun 2020. Program ini merupakan perkembangan dari program serupa yang pernah dijalankan pada tahun-tahun sebelumnya, yaitu program Kawasan Rumah Pangan Lestari yang menjadi P2L dalam upaya memperluas penerima manfaat dan pemanfaatan lahan [8].

Kegiatan P2L dilaksanakan dalam rangka mendukung program pemerintah untuk penanganan daerah prioritas intervensi stunting dan/atau penanganan prioritas daerah rentan rawan pangan atau pemantapan daerah tahan pangan. Kegiatan ini dilakukan melalui pemanfaatan lahan pekarangan, lahan tidur dan lahan kosong yang tidak produktif, sebagai penghasil pangan dalam memenuhi pangan dan gizi rumah tangga, serta berorientasi pasar untuk meningkatkan pendapatan rumah tangga. Tujuan dari program P2L yaitu meningkatkan ketersediaan, aksesibilitas, dan pemanfaatan pangan untuk rumah tangga sesuai dengan kebutuhan pangan yang beragam, bergizi seimbang, dan aman serta meningkatkan pendapatan rumah tangga melalui penyediaan 
pangan yang berorientasi pasar. Dokumentasi contoh kegiatan - kegiatan program P2L disajikan pada Gambar 1 beikut.

Sasaran program P2L yaitu kelompok masyarakat dengan konsep pemberdayaan. Pemberdayaan masyarakat ialah proses pembangunan yang membuat masyarakat berinisiatif untuk memulai proses kegiatan sosial dalam memperbaiki situasi dan kondisi diri sendiri [9]. Pemberdayaan masyarakat hanya bisa terjadi apabila masyarakat itu sendiri ikut pula berpartisipasi. Tujuan pemberdayaan adalah perbaikan kelembagaan, perbaikan usaha, perbaikan pendapatan, perbaikan lingkungan, perbaikan kehidupan, dan perbaikan masyarakat [10].

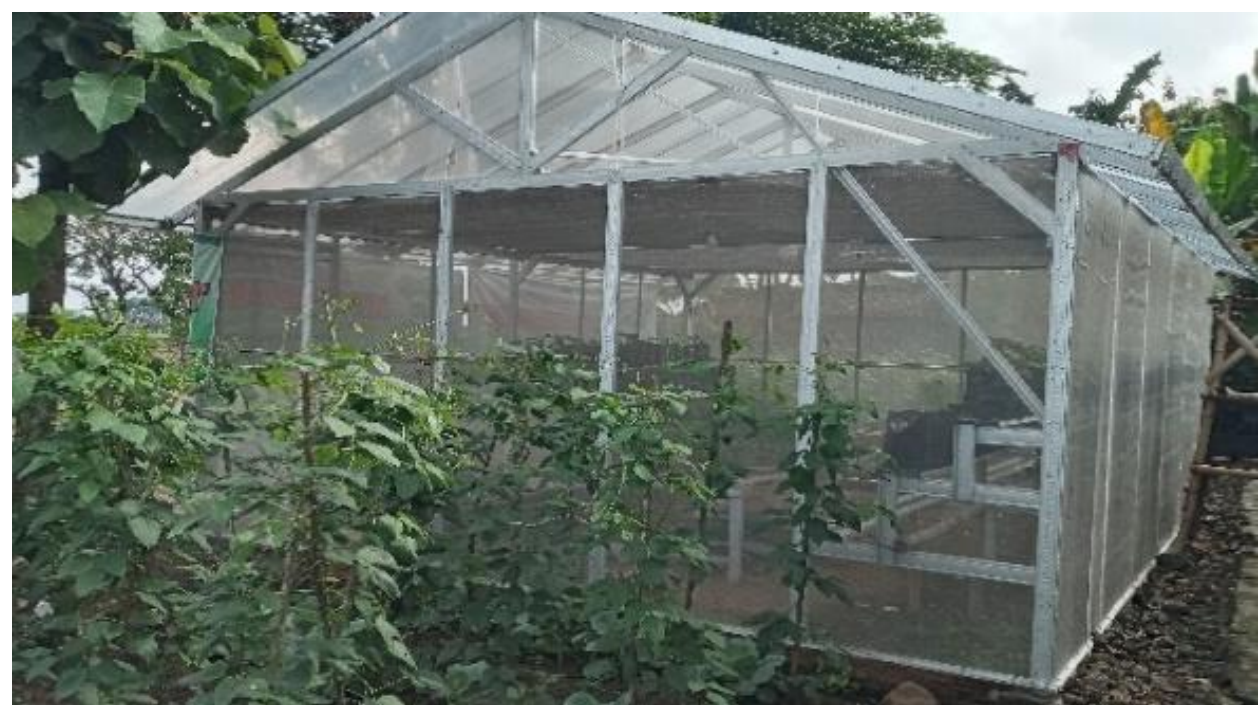

a. Kebun Bibit Desa
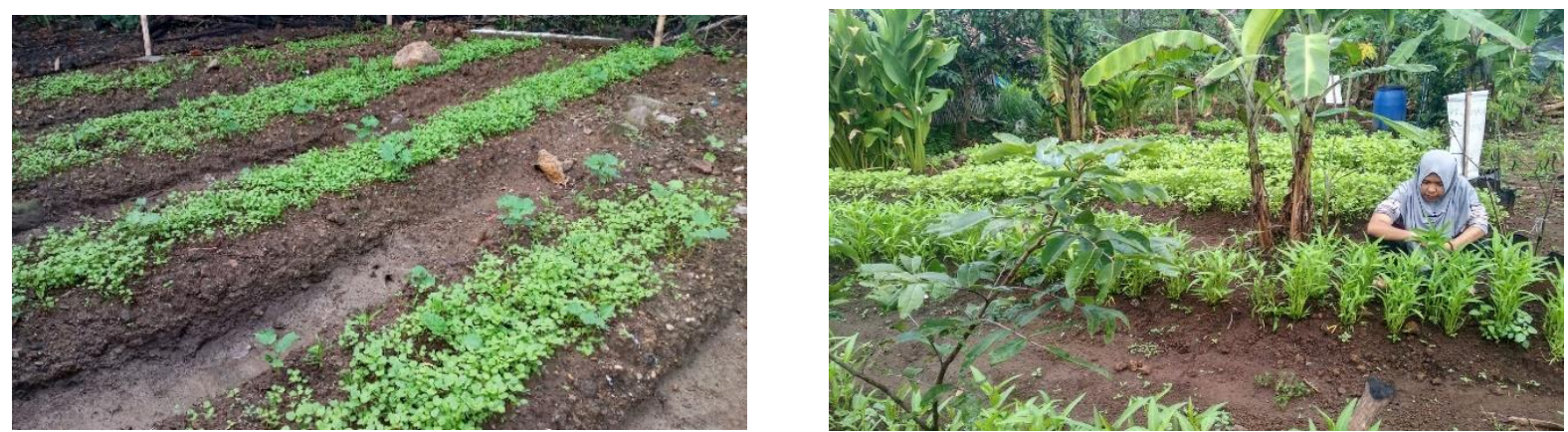

b. Demplot Tanaman Sayur Program P2L

Gambar 1. Pelaksanaan Program P2L di Kecamatan Gondangrejo

Kelompok masyarakat yang dimaksud yaitu karang taruna, pondok pesantren/santri tani, kelompok wanita tani, ibu-ibu PKK atau kelompok lainnya. Kelompok Wanita Tani (KWT) terbentuk oleh sekumpulan wanita tani dalam suatu lingkup tertentu dengan adanya minat dan tujuan yang sama. KWT merupakan salah satu penggerak komunitas tani agar dapat bersaing di pasaran dan meningkatkan kesejahteraan [11]. Pelaksana program P2L di Kecamatan Gondangrejo adalah kelompok wanita tani. Terdapat 3 kelompok wanita tani di
Kecamatan Gondangrejo yang mejadi penerima manfaat program P2L, yaitu KWT Jesa Karya di Desa Jeruksawit, KWT Kenanga di Desa Wonosari, dan KWT Putri Mandiri di Desa Rejosari.

Menurut petunjuk teknis program $\mathrm{P} 2 \mathrm{~L}$, kriteria calon penerima manfaat program P2L pada tahap penumbuhan atau tahap awal yaitu:

- Jumlah anggota kelompok P2L sebanyak 30 orang dalam satu kelompok, dimana setiap kelompok terdiri dari 3 pengurus dan 27 anggota; 
- Kelompok terpilih memiliki kelembagaan dan struktur organisasi/kepengurusan yang disahkan oleh kepala desa/lurah/pejabat yang berwenang;

- Kelompok Tani/Gapoktan/KUB yang terdaftar pada aplikasi Sistem Informasi Manajemen Penyuluhan Pertanian (Simluhtan) atau jika tidak teridentifikasi dalam Simluhtan, maka kelompok masyarakat harus memiliki legalitas yang disahkan oleh lembaga yang berwenang;

- Belum pernah mendapatkan dana bantuan pemerintah pada kegiatan yang sama.

- Memiliki rekening bank;

- Mampu menyediakan lahan untuk kebun bibit dan demplot (bukan menyewa lahan) minimal selama lima tahun yang dituangkan dalam surat perjanjian;

- Sanggup melaksanakan kegiatan sesuai petunjuk teknis yang dibuktikan dengan menandatangani pakta integritas kegiatan P2L;

- Syarat tambahan yaitu kelompok tersebut aktif sehingga terbentuk dinamika kelompok, mau berbudidaya pertanian terutama sayur, dan mau dibina oleh penyuluh setempat.

Implementasi program P2L pada KWT di Kecamatan Gondangrejo sudah berjalan sejak tahun 2020. Tahun-tahun sebelumnya KWT di Kecamatan Gondangrejo melaksanakan KRPL. Program P2L terbagi menjadi 2 kategori, yaitu kategori aspirasi dan stunting. Kategori aspirasi merupakan usulan dari Dewan Perwakilan Rakyat (DPR) ke Badan Ketahanan Pangan (BKP). Kategori stunting merupakan desa yang termasuk dalam wilayah stunting. Lokasi program P2L pada kategori stunting ditentukan oleh data wilayah stunting yang dimiliki oleh Dinas Kesehatan, kemudian Dinas Pertanian PP memiliki wewenang untuk memilih desa mana yang akan diberi program tersebut.

KWT Jesa Karya di Desa Jeruksawit dan KWT Kenanga di Desa Wonosari merupakan pelaksana program P2L pada kategori aspirasi. KWT Putri Mandiri di Desa Rejosari merupakan pelaksana program P2L pada kategori stunting. Pelaksanaan program P2L pada kategori stunting dipantau oleh Dinas Pertanian PP untuk teknik serta administrasi pertanian dan Dinas Kesehatan Kabupaten Karanganyar untuk kualitas gizi bagi anak-anak stunting.

Implementasi program P2L pada KWT di Kecamatan Gondangrejo tergolong sudah berjalan sesuai dengan petunjuk teknis. Program P2L membawa berbagai dampak yang dirasakan oleh anggota KWT dan keluarganya. Dampak yang diperoleh masyarakat ditinjau dari aspek ekonomi, sosial, budaya, psikologis, dan aspek lingkungan.

Berikut diuraikan dampak-dampak yang dihasilkan dari kegiatan P2L:

\section{Aspek ekonomi}

Dampak pada aspek ekonomi merupakan dampak yang ditinjau pada peningkatan pendapatan masyarakat penerima Program. Berdasarkan hasil pengamatan dan wawancara dengan masyarakat, Program P2L di Kecamatan Gondangrejo belum sampai pada peningkatan pendapatan anggotanya, akan tetapi mampu mengurangi pengeluaran rumah tangga dan pemenuhan kebutuhan konsumsi rumah tangga. Kebutuhan rumah tangga baik sandang, pangan dan papan pasti selalu ada. Pangan merupakan kebutuhan primer yang harus dipenuhi setiap hari. Kebutuhan akan pangan yaitu makanan dan minuman yang didalamnya menyangkut sayursayuran sebagai sumber gizi keluarga. Program P2L sangat membantu dalam pemenuhan kebutuhan pangan tersebut melalui kegiatan budidaya tanaman sayur yang dapat dibudidayakan di pekarangan masing-masing anggota.

Dampak dari segi ekonomi dapat terlihat dari berkurangnya pengeluaran anggota KWT untuk belanja sayur. Anggota KWT memiliki pertanaman di pekarangan rumah masingmasing dan ketika tiba waktu panen, mereka dapat mengonsumsi sesuai dengan kebutuhan masing-masing. Hasil pertanaman pada demplot kelompok dapat juga dinikmati oleh para anggota KWT dengan cara membeli yang tentunya dengan harga yang lebih murah atau bahkan gratis. Hal tersebut membuat pengeluaran keluarga untuk belanja sayur akan semakin berkurang.

Konsumsi sayuran menjadi menu sehat yang wajib dipenuhi sesuai kebutuhan tubuh. Terpenuhinnya kebutuhan sayur akan membuat kondisi masyarakat terutama anggota KWT beserta keluarga yang sehat dan terhindar dari penyakit. Kesadaran masyarakat membuat mereka memilih untuk mengonsumsi sayuran organik dan terbebas dari bahan-bahan kimia. Aktivitas budidaya tanaman sayur pada program P2L di Kecamatan Gondangrejo ini menjadi peluang yang sangat baik untuk mampu 
mencukupi kebutuhan konsumsi rumah tangga yang beragam dan bergizi seimbang.

Program P2L di Kecamatan Gondangrejo memang belum pada kategori menghemat anggaran belanja dalam jumlah besar, tetapi setidaknya dapat menghemat pengeluaran belanja sayur. Berdasarkan wawancara yang dilakukan, wanita tani dapat menghemat belanja sayur yang berkisar antara Rp50.000 hingga Rp70.000 per bulan. Melalui penghematan tersebut, anggarannya dapat dialihkan untuk anggaran belanja kebutuhan yang lain. Hal ini sejalan dengan penemuan sebelumnya, yang menyatakan bahwa program optimalisasi kebun dan pekarangan memberikan peluang dana yang seharusnya dibelikan sayur dapat dialokasikan untuk membeli bahan pokok lain [12]. Program P2L di sini juga belum bisa dijadikan sebagai sumber penghasilan utama anggota KWT, namun yang terpenting adalah adanya pengembangan peningkatan kualitas hidup yang lebih baik melalui program ini.

\section{Aspek sosial}

Aspek sosial yang dimaksud adalah tentang pergaulan hidup dalam kehidupan bermasyarakat yang mengandung nilai-nilai kebersamaan. Norma sosial yang mengatur interaksi masyarakat dan solidaritas sebagai unsur pemersatu karena manusia sebagai makhluk sosial yang tidak dapat hidup sendiri, melainkan membutuhkan bantuan dari orang lain. Kategori aspek sosial tersebut adalah perubahan perilaku, dinamika kelompok, dan peningkatan keterampilan.

Perubahan perilaku yang terjadi adalah anggota yang dulunya jarang berinteraksi dengan tetangga atau masyarakat, dengan adanya kegiatan P2L ini maka mereka mulai aktif untuk melakukan interaksi dengan tetangga yang juga menjadi anggota KWT. Hubungan timbal balik ini menjadi penunjang terlaksananya program P2L di desa setempat. Dampak positif lain yang dirasakan yaitu terdapat dinamika kelompok, dimana anggota dapat berpartisipasi dalam kegiatan sosial, saling bekerjasama dan tolong-menolong antar anggota sehingga meningkatkan kualitas hidup yang lebih baik sebagai tujuan dari pemberdayaan. Fungsi dari dinamika kelompok yaitu membentuk kerjasama saling menguntungkan dalam mengatasi persoalan hidup, memudahkan pekerjaan, mengatasi pekerjaan yang membutuhkan pemecahan masalah dan mengurangi beban pekerjaan yang terlalu besar sehingga lebih cepat selesai, efektif, dan efisien serta menciptakan iklim demokratis dalam kehidupan masyarakat [13].

Penyuluhan dan pendampingan yang diberikan oleh PPL Kecamatan Gondangrejo dalam penerapan program P2L yaitu memaksimalkan pemanfaatan lahan pekarangan dan lahan kosong. Materi penyuluhan terkait dengan budidaya tanaman sayur mulai dari pembenihan, pembibitan, pertanaman, hingga panen dan pasca panen dilakukan secara bersama-sama oleh KWT. Penyuluhan ini memiliki dampak yang dirasakan oleh KWT di Kecamatan Gondangrejo, yaitu para anggota dengan terampil dan mandiri membudidayakan tanaman sayur untuk dapat dikonsumsi seharihari.

\section{Aspek budaya}

Berbeda dengan aspek ekonomi dan sosial, aspek budaya ini belum terlihat selama kegiatan P2L berlangsung. Faktor budaya memberikan pengaruh paling luas dan mendalam pada tingkah laku konsumen [14]. Harapan ke depan, program P2L dapat lebih dikembangkan dan membawa dampak bagi kebudayaan setempat. Aspek budaya diharapkan mampu memberi nilai positif program dan membuat masyarakat semakin tertarik untuk ikut melaksakan program P2L.

\section{Aspek psikologis}

Pengetahuan dan keterampilan mengenai budidaya tanaman sayur semakin bertambah seiring berjalannya waktu. Pertemuan KWT yang intens dilakukan membuat anggota lebih berpikir kritis, saling bertegur sapa dan menumbuhkan kebersamaan antar anggota kelompok. Gotong-royong antar anggota semakin terlihat menunjukkan adanya dampak dari program $\mathrm{P} 2 \mathrm{~L}$ yang telah berjalan.

Kemampuan wanita tani dalam mengontrol emosi, menjadi bagian dari suatu organisasi membuat masing-masing individu harus bisa memberi dan menerima masukan maupun pendapat orang lain. Individu yang tadinya egois ketika masuk organisasi akan bisa mengontrol keegoisan individu dan memberikan kesempatan bagi orang lain untuk dapat menyampaikan pendapatnya. Hal ini ditunjukkan ketika kegiatan pertemuan KWT, dimana wanita tani tidak saling memaksakan kehendak dan mampu menerima apabila pendapatnya ada yang tidak 
disetujui oleh forum. Rasa mau untuk belajar akan hal-hal baru mengenai budidaya tanaman sayur juga merupakan wujud dari dampak program P2L apabila ditinjau dari aspek psikologis.

\section{Dampak terhadap lingkungan}

Manusia sebagai makhluk sosial yang melakukan hubungan timbal balik dengan sesamanya juga membutuhkan lingkungan sebagai sarana pendukung. Lingkungan tempat tinggal khususnya lahan pekarangan rumah menjadi sarana tempat terlaksananya program P2L dimanapun berada. Anggota kelompok memanfaatkan pekarangan untuk pertanaman sayur-sayuran dan buah-buahan dengan menggunakan polybag, ditanam langsung di lahan maupun secara vertikultur.

Dampak lingkungan yang terjadi setelah adanya program P2L yaitu tanah tidak tercemar, karena budidaya tanaman sayur menggunakan bahan-bahan organik. Media tanam, pupuk, pestisida, dan fungisida yang digunakan dalam program P2L ini terbuat dari bahan organik. Tersedianya daerah resapan air pada suatu daerah atau kawasan dapat mengurangi risiko terjadinya banjir. Pekarangan anggota KWT yang dulunya merupakan lahan kosong bisa menjadi bagus karena dirawat dan menjadi tempat budidaya sayur, sehingga tidak kosong lagi dan bisa menghasilkan. Terciptanya keindahan, membantu mengurangi laju pemanasan global, menciptakan lingkungan yang bersih dan tertata dapat menyegarkan mata dan pikiran setelah seharian melakukan aktivitas padat di luar rumah.

Sejalan dengan penelitian sebelumnya pada program KRPL yang menyatakan bahwa salah satu program kementerian pertanian dalam rangka optimalisasi lahan pekarangan yang ramah lingkungan dalam suatu kawasan [15]. Begitu pula dengan program P2L yang merupakan program optimalisasi lahan pekarangan yang ramah lingkungan. Tidak ada dampak buruk yang ditimbulkan karena pelaksanaan program ini.

\section{KESIMPULAN}

Program Pekarangan Pangan Lestari (P2L) pada KWT di Kecamatan Gondangrejo Kabupaten Karanganyar sudah berjalan dengan baik. Dampak nyata terlihat dari aspek ekonomi, hasil budidaya sayur dapat dinikmati oleh anggota dapat membantu mengurangi pengeluaran belanja serta memudahkan aksesibilitas keluarga untuk memperoleh pangan yang beragam dan bergizi. Dampak sosial terlihat dari adanya perubahan perilaku, hubungan timbal balik antar anggota, terbentuknya dinamika kelompok. Dampak aspek psikologis tampak dari kemauan anggota untuk belajar sehingga anggota menjadi semakin terampil; dan dampak terhadap lingkungan yaitu tidak adanya pencemaran lingkungan serta membuat keindahan di pekarangan rumah. Dampak dari aspek budaya belum terlihat dari pelaksanaan program P2L di Kecamatan Gondangrejo.

\section{UCAPAN TERIMA KASIH}

Penulis mengucapkan terima kasih kepada seluruh pihak yang telah membantu dalam keberjalan proses penelitian dari awal hingga akhir. Terima kasih Bapak, Ibu, dan Kakak yang senantiasa mendukung dalam proses penyelesaian penelitian ini dari awal hingga akhir. Terima kasih kepada teman, sahabat yang juga memberi semangat.

\section{DAFTAR PUSTAKA}

[1] BKP. (2020). Petunjuk Teknis P2L (Pekarangan Pangan Lestari). Jakarta: Departemen Pertanian.

[2] Nurcahyanti, P., Eny, L., \& Sutarto, S. (2017). Hubungan Dinamika Kelompok dengan Partisipasi Anggota Kelompok Wanita Tani dalam Program Kawasan Rumah Pangan Lestari (KRPL) di Kecamatan Tasikmadu Kabupaten Karanganyar. Agritexts, 41(1): 55-69.

[3] Singarimbun, M., \& Effendi, S. (2006). Metode Penelitian Survei Revisi. Jakarta: PT. Pustaka LP3ES.

[4] Rukajat, A. 2018. Teknik Evaluasi Pembelajaran.Yogyakarta: Deepublish.

[5] Sugiyono. (2020). Metode Penelitian Kualitatif, untuk Penelitian yang Bersifat: Eksploratif, Enterpretatif, Interaktif, dan Konstruktif. Bandung: Alfabeta.

[6] Sutopo, H. B. (2002). Metodologi Penelitian Kualitatif. Surakarta: Universitas Sebelas Maret Press. 
[7] Nazir, M. (2011). Metode Penelitian, Cetakan Ke Tujuh. Bogor: Penerbit Ghalia Indonesia.

[8] BKP. (2021). Petunjuk Teknis Bantuan Pemerintah Kegiatan Pekarangan Pangan Lestari (P2L) Tahun 2021. Jakarta: BKP Kementerian Pertanian.

[9] Maryani, D. \& Nainggolan, R. R. E. (2019). Pemberdayaan Masyarakat. Yogyakarta: Deepublish.

[10] Mardikanto, T. (2015). Pemberdayaan Masyarakat. Bandung: Alfabeta.

[11] Syahroni, I., \& Amanah, S. (2018).

[12] Hubungan antara Gaya Kepemimpinan Ketua dan Efektivitas Kelompok Wanita Tani Toga. Jurnal Sains Komunikasi dan Pengembangan Masyarakat (JSKPM), 2(4): 441-454.
[13] Kurniasih, D. E., \& Joko, A. (2018). Kebun Gizi sebagai Strategi Berbasis Masyarakat untuk Memenuhi Kebutuhan Konsumsi. Berita Kedokteran Masyarakat, 34(2): 93-97.

[14] Sunarto, K. (1992). Sosiologi Kelompok. Jakarta: Pusat Antar Universitas IlmuPengetahuan Sosial Universitas Indonesia.

[15] Kotler, P. (2005). Manajemen Pemasaran, Edisi Milenium, Jilid 3. Jakarta: Penerbit Indeks.

[16] Sukanata, I, K, Budirokhman, D, \& Nurmaulana, A. (2015). Faktor-Faktor yang Mempengaruhi Pemanfaatan Lahan Pekarangan dalam Kegiatan Kawasan Rumah Pangan Lestari. Jurnal Agrojati. 28(1): 1-16. 